Canadian University Music Review

Revue de musique des universités canadiennes

\title{
Techniques of Unification in Tonally Deviating Works
}

\section{Harald Krebs}

Volume 10, numéro 1, 1990

URI : https://id.erudit.org/iderudit/1014895ar

DOI : https://doi.org/10.7202/1014895ar

Aller au sommaire du numéro

\section{Éditeur(s)}

Canadian University Music Society / Société de musique des universités

canadiennes

\section{ISSN}

0710-0353 (imprimé)

2291-2436 (numérique)

Découvrir la revue

\section{Citer cet article}

Krebs, H. (1990). Techniques of Unification in Tonally Deviating Works. Canadian University Music Review / Revue de musique des universités canadiennes, 10(1), 55-70. https://doi.org/10.7202/1014895ar

All Rights Reserved ( C Canadian University Music Society / Société de musique des universités canadiennes, 1990
Ce document est protégé par la loi sur le droit d'auteur. L'utilisation des services d'Érudit (y compris la reproduction) est assujettie à sa politique d'utilisation que vous pouvez consulter en ligne.

https://apropos.erudit.org/fr/usagers/politique-dutilisation/ 


\title{
TECHNIQUES OF UNIFICATION IN TONALLY DEVIATING WORKS
}

\author{
Harald Krebs
}

Schubert's song "Klage an den Mond" (Example 1), written in 1816, begins in $\mathrm{F}$ major but ends in $\mathrm{D}$ minor. The first and second stanzas mention, respectively, the poet's happy childhood (mm. 1-7) and his anguished present existence (mm. 12-19). In the final stanza (mm. 20ff.), the poet alludes to death: he muses that the moon that watched over his childhood and over his present agony will soon shine on his tombstone. Schubert sets the two stanzas concerned with life in a similar manner. Melody and key remain the same; the increased pathos in the second stanza is simply reflected by an increase in chromaticism. The stanza concerned with death, on the other hand, is set in a completely different manner. Not only does Schubert employ entirely new thematic material but, remarkably, he deviates from his opening tonic, never to return; he abruptly establishes the key of D minor and ends therein.

The distinctive tonal structure of this short work illustrates a tendency, prevalent among nineteenth-century composers, to explore alternatives to the conventions of earlier tonal practice. The deviation from and permanent abandonment of the opening tonality of a composition is one of the most revolutionary of their novel practices. While it must be noted that some dabbling in "tonal deviation" had taken place prior to the nineteenth century - with some isolated examples of deviating works and movements by Corelli, J. S. Bach, Mozart, Beethoven and others ${ }^{1}$ - there is undeniably an upswing in the production of deviating works in the nineteenth century, the primary exponents of tonal deviation in the first half of the century being Schubert and Chopin. Several important works by Chopin, namely the Scherzo Op. 31, the Ballade Op. 38 and the Fantasy Op. 49, do not close in their opening keys. The same is true of approximately sixty of Schubert's Lieder, most of them written in his early years (1813-1816).

1 Examples include the first movement of Corelli's Sonata Op. 1 No. 5 (Bb major to $\mathrm{G}$ minor), the "Crucifixus" from Bach's Mass in B minor (E minor to $\mathrm{G}$ major), Mozart's aria "Solch hergelauf'ne Laffen" from Die Entführung aus dem Serail, and Beethoven's Fantasy Op. 77 (G minor to B major). 
Klage.

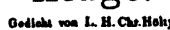

Fur eine Singstimme mil Begleiturig des Pianoforte nomponirt ron

FRANZ SCHUBERT.

Singotimme.

(96)

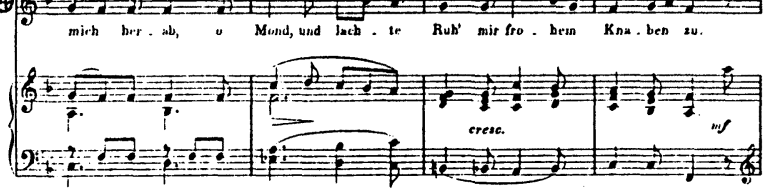

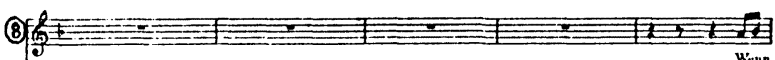

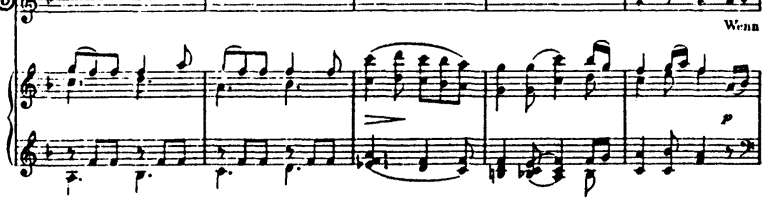

(3)

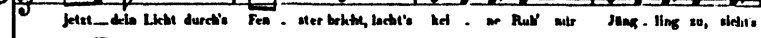

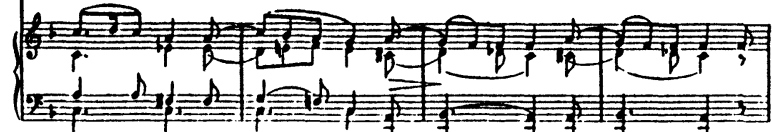

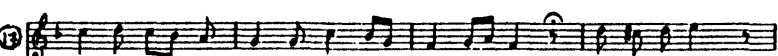

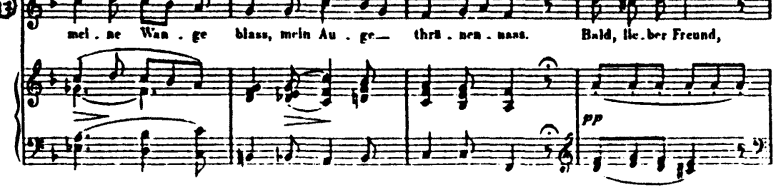

(12)

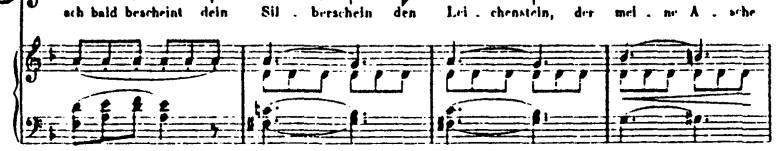

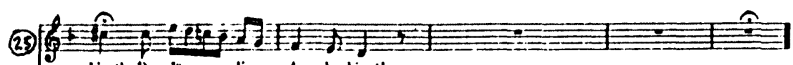

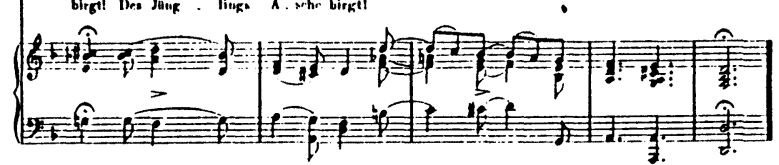

Example 1: Schubert, "Klage" 
Even a relatively simple deviating work like Schubert's "Klage" raises provocative questions. For example, does the work really progress from one key to another, or can it somehow be understood as lying within a single tonic? If there is a single tonic, is it the initial or the final one $?^{2}$ Why do composers depart from the norm of tonal unity? Finally, how are deviating works unified in the absence of an overarching single tonality?

I propose to investigate only the last of the above questions here. Let us begin by more closely defining the problem of unity in a deviating work. In a normal tonal work, the tonic triad exercises a twofold unifying function. First, once it has been employed as the beginning point of a work, the tonic triad is the expected endpoint; its presence at the end of the work ties up and rounds off that work in a satisfying manner. Second, in a normal tonal work the tonic triad is the center of gravity around which all harmonies ultimately revolve the reference point with respect to which they are understood. Neither of these unifying functions is operative in a tonally deviating work. The opening tonic does not return at the end to round off the work. Nor does that tonic exercise a continuous gravitational force; at some point, that triad ceases to govern the harmonic flow and its tonic status is usurped by one or more different triads. The resulting lack of tonal unity undoubtedly poses a serious threat to the viability of a composition. The opening tonic could easily become a loose end, and the final triad a weak, unsatisfying substitute for the expected opening tonic. There is also a danger that, in the absence of a "background" tonic which perceptibly acts as a center of gravity, the work could become a chaotic jungle of aimless, haphazard progressions. Composers of tonally deviating works were confronted with the problem of avoiding these pitfalls and arriving at some way of ensuring unity and coherence.

The study of tonally deviating works reveals various responses to this problem, only two of which will be addressed here. ${ }^{3}$ First, the final tonic (hence-

2 Schenker's analyses of deviating works argue in favour of the supremacy of the final tonic. I have attempted to show that the opening tonic is frequently as important as, or more important than the final tonic; see, for example, my review of Chopin Studies, ed. Jim Samson, in Journal of Music Theory, to appear in Fall, 1989.

3 I have discussed other methods of unification in other papers: "Dyadic Unification in Tonally Deviating Works," read at the symposium Alternatives to Monotonality at the University of Victoria in February, 1989, and "Melodic Techniques of Unification in Tonally Deviating Works," read at the meeting of the Pacific Northwest Chapter of the American Musicological Society in Edmonton, April, 1989. 
forth called Y) may be foreshadowed during the initial portion of a deviating work, with the result that its eventual assumption of a tonic role is a logical outcome of prior events rather than a haphazard occurrence. Second, the initial tonic (henceforth called X) may be recalled within the final area of a deviating composition and may, moreover, be explicitly subordinated to and resolved into $\mathrm{Y}$. The tonal thread of $\mathrm{X}$, rather than remaining a loose end, is thus picked up and tied into $\mathrm{Y}$ before the work comes to a close. Let us look at some examples of these techniques.

\section{Foreshadowing techniques}

The simplest possible means of foreshadowing is the placement of a single, prominent harmony suggestive of the key of $Y$ within the area of the work governed by $\mathrm{X}$. The key word here is "prominent"; the argument for the presence of deliberate foreshadowing is most convincing if the reference to $Y$ is somehow marked for consciousness, for example by its placement at an important structural point, by dynamic emphasis or by prolongation.

The obvious chord choices for the purpose of such foreshadowing are I of $\mathrm{Y}$ and $\mathrm{V}$ of $\mathrm{Y}$; both point clearly toward the final key area. Schubert's song "Klage an den Mond" exemplifies the use of $\mathrm{V}$ of $\mathrm{Y}$ as a foreshadowing chord (see Example 1). Within the second strophe, the V of Y triad appears twice (mm. 14 and 15). These statements of $\mathrm{V}$ of $\mathrm{Y}$ may not seem particularly prominent. In context, however, these chords do stand out; since they are not present at the corresponding point of the first strophe (cf. mm. 2 and 3), they attract the listener's attention when they unexpectedly appear in the second. It seems likely that they were deliberately introduced to foreshadow the new key of the third strophe.

In Schubert's song "Laura am Klavier" (first version), the final tonic is foreshadowed not merely by brief statements of $\mathrm{V}$ of $\mathrm{Y}$, but by a prolongation of that harmony. The song begins in $\mathrm{E}$ major and ends in $\mathrm{B}$ flat major. The excerpt shown in Example 2 is found close to the beginning of the work; the initial establishment of the key of $E$ major is followed by a restatement of the opening material in the subdominant of that key, which in turn is followed by the quoted passage. This passage is conspicuous because of its harmonic remoteness from X; the use of the tritone relation at so early a point within the composition is quite striking. Further highlighting of the passage is achieved by the use of new thematic material and by a sudden drop in dynamic level. Interestingly enough, the corresponding point of the extensively revised second version includes no comparable passage. The reason for the omission becomes clear when one looks at the end of that version. The final key is now the same as the opening key rather than being a tritone removed; there is thus no need for a preparatory allusion to the tritone relation in the opening music. 


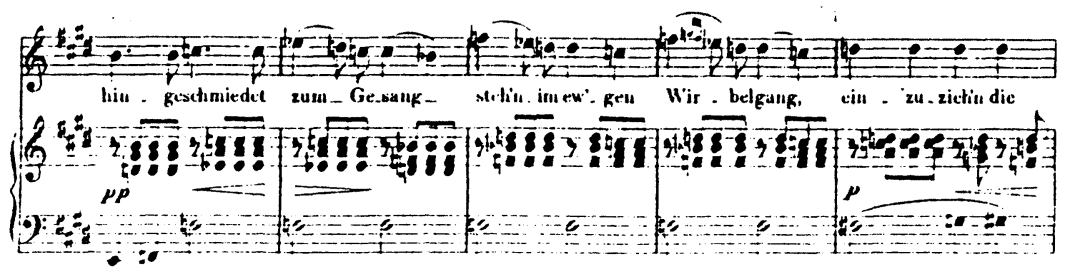

Example 2: Schubert, "Laura am Klavier". Foreshadowing by prolongation of $\mathrm{V}$ of $\mathrm{Y}$

In the preceding examples, the foreshadowing elements were verticalities, prolonged or unprolonged. Foreshadowing of $Y$ by the statement of a single Y-related harmony may, however, also occur in the horizontal dimension. The opening of Schubert's song "Der Alpenjäger" (Example 3) serves as an illustration. The song begins in C major and ends in A major. The vocal line begins with subtle allusions to the final key (in its minor mode); arpeggiations of the A minor triad are implied in mm. 5-7. ${ }^{4}$ That harmony is not, to be sure, brought to the fore at this point; the harmonic support for the vocal line lies so solidly within the opening key of $\mathrm{C}$ that the vocal "arpeggiations" of $\mathrm{A}$ minor remain bloodless wraiths. However, at the end of the opening section (mm. 14-15 and 20-23), the A triad makes significant strides toward its final status as principal harmony: further melodic allusions to $\mathrm{A}$ minor do receive strong harmonic support. Only in the final eight measures of the lengthy composition, where A major becomes the incontrovertible tonic, will these initial implications be fully realized.

Much foreshadowing involves the linking of the tonic notes or triads of $X$ and $Y$, either in the horizontal or the vertical dimension, rather than the statement of an isolated $\mathrm{Y}$-related harmony. Such $\mathrm{X} / \mathrm{Y}$ associations, placed in the context of the initial $\mathrm{X}$ prolongation, may act either as surface-level reflections of the large $\mathrm{X}$ to $\mathrm{Y}$ progression that will take place in the work or as surface-level expressions of the large scale conflict between two tonics that will underlie the work. The overall $\mathrm{X}$ to $\mathrm{Y}$ progression is anticipated by horizontal association of $\mathrm{X}$ and $\mathrm{Y}$. The large scale conflict between two tonics inherent in deviating works, on the other hand, is most aptly foreshadowed by

4 In Schubert's music, as in much nineteenth-century music, shifting between major and minor modes of a given tonic is so common that one cannot convincingly assign a particular mode to a given piece. Schubert's choice of the "wrong" mode of his final tonic for foreshadowing purposes is in tune with his typical mixing of the two modes. See also Example 6. 


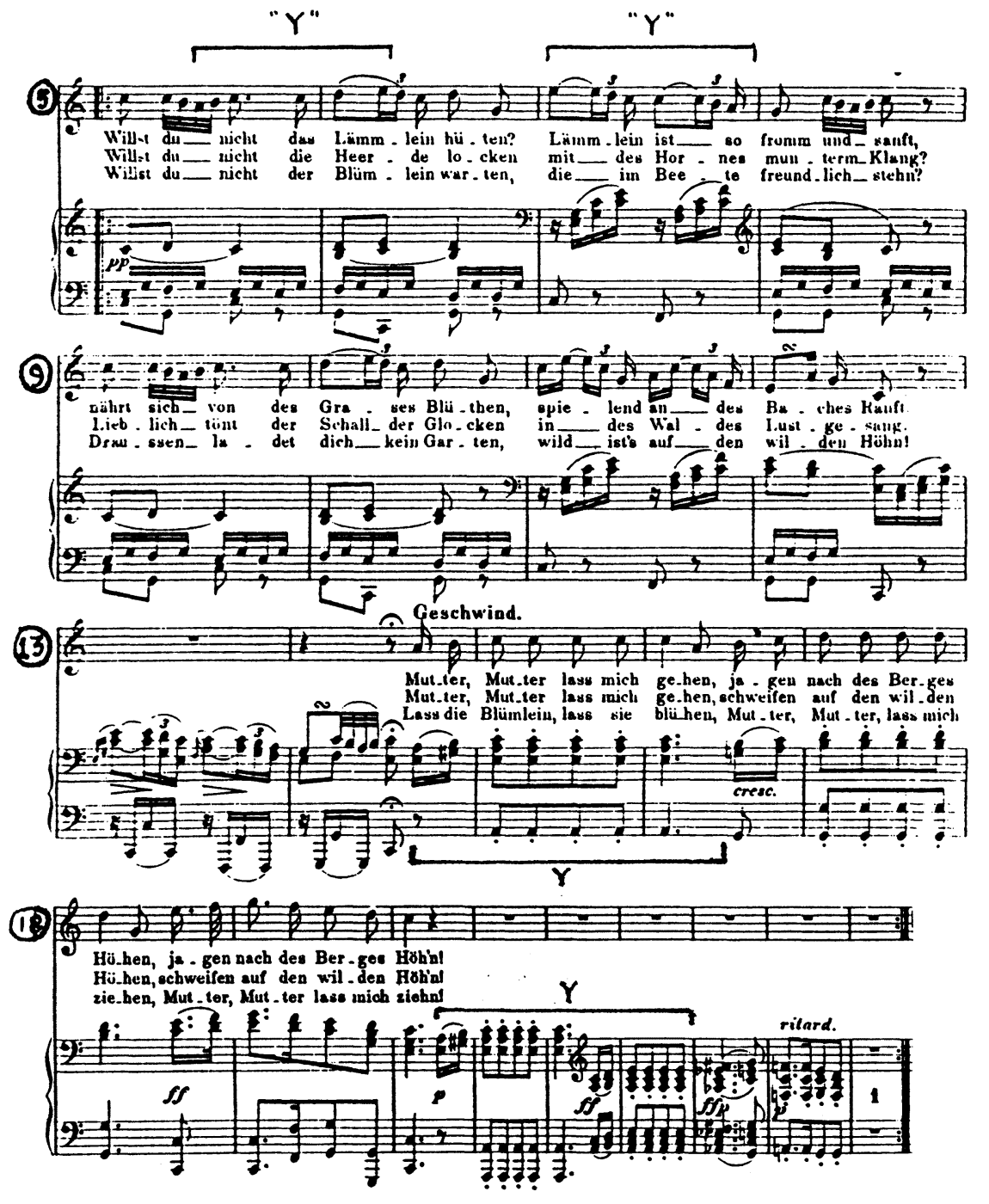

Example 3: Schubert, "Der Alpenjäger", mm. 5-26. Foreshadowing by arpeggiation 


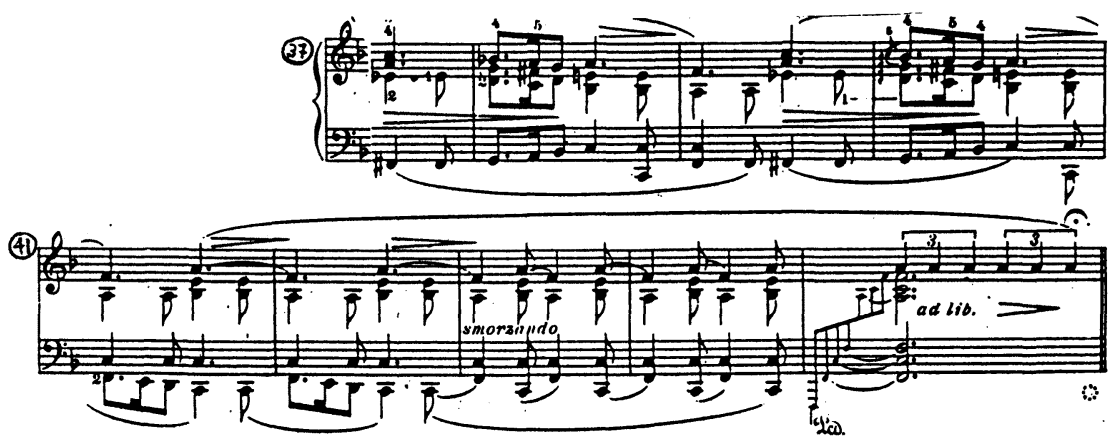

Example 4: Chopin, Ballade Op. 38, mm. 37-45. Foreshadowing by juxtaposition of the tonic notes of $\mathrm{X}$ and $\mathrm{Y}$

vertical associations of $\mathrm{X}$ and $\mathrm{Y}$, which are invariably dissonant and thus indicative of conflict.

Example 4, from Chopin's Ballade Op. 38, illustrates a simple type of horizontal association: the juxtaposition of the tonic notes of $\mathrm{X}(\mathrm{F})$ and $\mathrm{Y}(\mathrm{A})$ within a melodic line. At a significant juncture of the work, namely at the end of the initial Andantino section, the melody oscillates for some time between $A$ and $F$, finally settling on $A-$ an ingenious anticipation of the coming large scale progression, which will waver back and forth between the keys of $F$ major and $\mathrm{A}$ minor before coming to rest on the latter tonic.

Example 5 illustrates foreshadowing of the overall $\mathrm{X}$ to $\mathrm{Y}$ motion by a juxtaposition of the tonic triads of $\mathrm{X}$ and $\mathrm{Y}$, rather than merely the tonic notes. The overall tonal motion of Schubert's song "Edone", Eb major to $\mathrm{C}$ minor, is anticipated not only by the foreground progression of the first measure but also by the first two middleground harmonies; the first phrase of the song (mm. 1-6) prolongs $X$, while the second phrase (mm. 7-11) prolongs $Y$.

An early nineteenth-century composer's experiment with foreshadowing by vertical association of the $\mathrm{X}$ and $\mathrm{Y}$ triads is shown in Example 6. Schubert's massive song "Einsamkeit" begins in B flat major and ends in G major. In $\mathrm{mm}$. 1 to 5, Schubert not only outlines the harmonic path that will be travelled in the song by writing a progression leading from the $X$ triad to a chord built on $\mathrm{Y}$, but also prominently superimposes the $\mathrm{X}$ and $\mathrm{Y}$ triads (see the dynamically accentuated chord in $\mathrm{m}$. 5). The same superimposition recurs in $\mathrm{m} .10$. To be sure, within this conglomerate the $\mathrm{Y}$ triad is not presented in the mode that will be used at the end of the work; the combination of the $\mathrm{X}$ triad with 


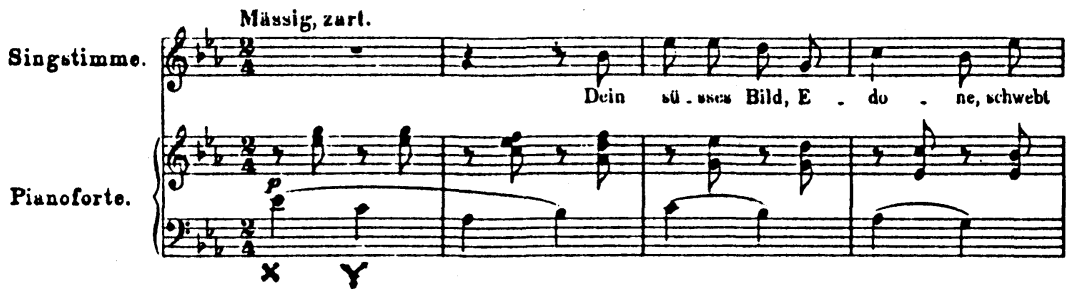

(5)

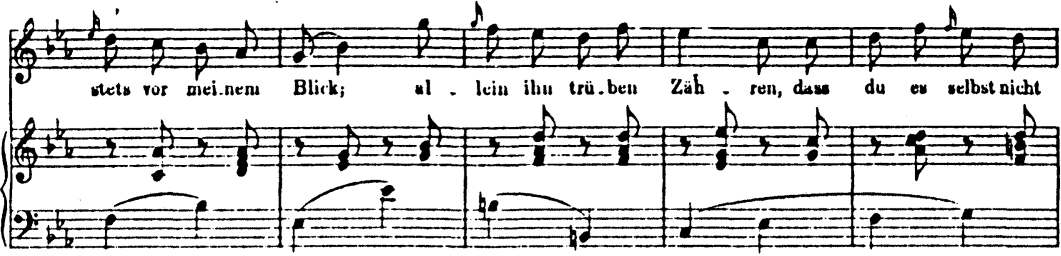

(10)

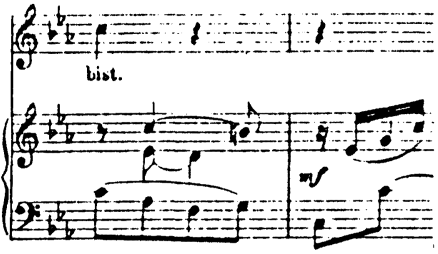

Example 5: Schubert, "Edone", mm. 1-11. Foreshadowing by juxtaposition of $\mathrm{X}$ and $\mathrm{Y}$ harmonies on two levels

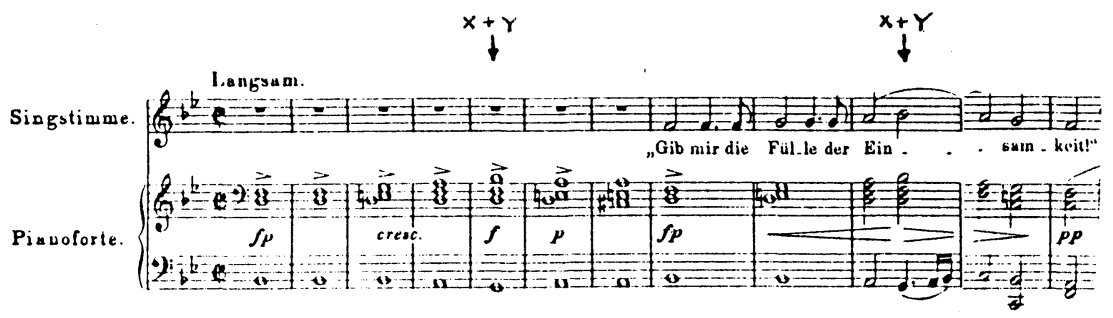

Example 6: Schubert, "Einsamkeit", mm. 1-12. Foreshadowing by superimposition of $\mathrm{X}$ and $\mathrm{Y}$ harmonies 
the major form of $\mathrm{Y}$ would have resulted in a dissonance of intolerable harshness for this period. The suggestion of a superimposition of $\mathrm{X}$ and $\mathrm{Y}$, however, is certainly present.

\section{Techniques of Recall}

Although they involve X-related rather than Y-related pitches, and occur in the context of $\mathrm{Y}$ rather than that of $\mathrm{X}$, the techniques of recall in tonally deviating works are essentially the same as those of foreshadowing. That is, recall, like foreshadowing, takes place by reference to an isolated element of the non-governing key, or by association in the horizontal or vertical dimension of elements of both the governing and the non-governing keys. One unique aspect of passages of recall, briefly mentioned earlier, must be stressed: recall is associated with the explicit subordination of $\mathrm{X}$ to $\mathrm{Y}$. The subservience of $\mathrm{X}$ to $\mathrm{Y}$ may, for instance, be clarified by allotting to $\mathrm{X}$ a secondary harmonic function within the key of $Y$. The function of dominant preparation is commonly selected for this purpose. Casting the note $X$ or the $X$ triad into the role of a contrapuntal embellishment of the $Y$ triad (for example, as a neighbouring or passing note or chord), is another common method of indicating the subordination of $\mathrm{X}$ to $\mathrm{Y}$. A few examples of passages of recall will clarify the techniques involved.

The last few measures of Schubert's "Klage an den Mond" (see Example 1) illustrate recall by reference to the $\mathrm{X}$ triad and by superimposition of $\mathrm{X}$ and $\mathrm{Y}$. The suspension at the beginning of $\mathrm{m} .27$ creates a momentary $\mathrm{X} / \mathrm{Y}$ conglomerate. When the suspension resolves, the pure $X$ triad ( $F$ major) emerges equally briefly and is then led through a diminished seventh chord to the $\mathrm{Y}$ triad. The function of the $\mathrm{X}$ triad at this point is that of a neighbouring chord between the $Y$ triads of $m$. 26 and 27. By presenting the $X$ triad as an embellishment of the new tonic, Y, Schubert makes clear that $X$ now has a subordinate function, that it has been demoted from its former tonic status and has been engulfed by the key of Y.

The ending of Schubert's song "Der Liedler" (Example 7) illustrates recall by juxtaposition of $X$ (A minor) and $Y$ (Ab major). Fourteen measures before the end of the work, the minor $\mathrm{Y}$ and the $\mathrm{X}$ triads are employed as the goal harmonies of adjacent segments of a sequence. Since the sequence is not continued beyond these two segments, it throws the two conflicting tonics of the song into prominent relief. Immediately after the sequence, the $X$ triad is pressed into the duty of a dominant preparation (flat II) within $\mathrm{Y}$ and is thus absorbed into the latter key. 


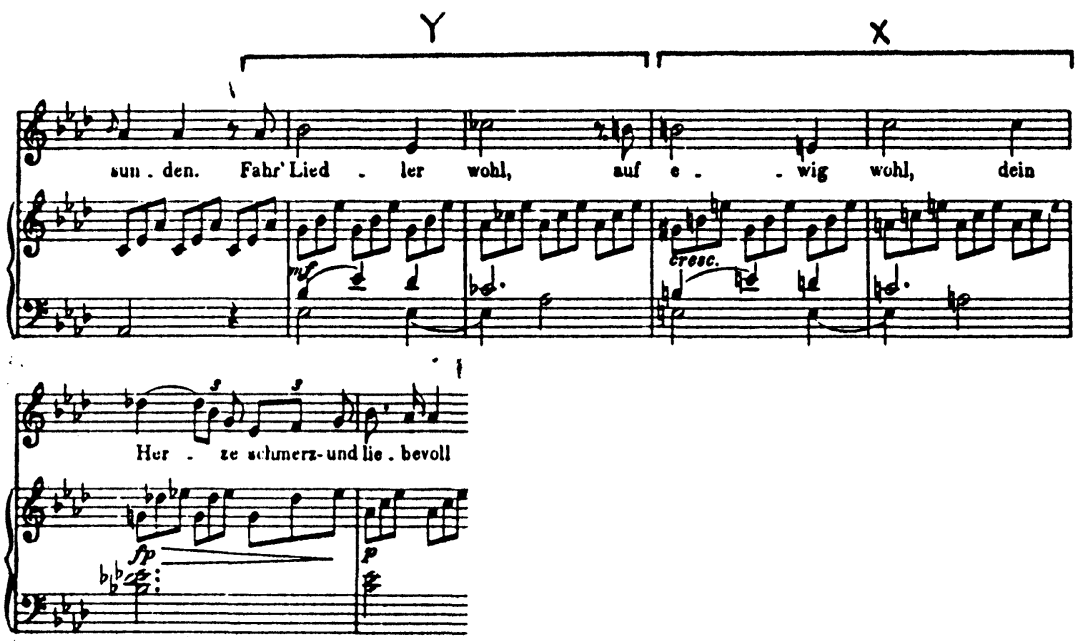

Example 7: Schubert, "Der Liedler". Recall by juxtaposition of $X$ and $Y$

Recall by superimposition is powerfully employed in Chopin's Ballade Op. 38. Examples $8 \mathrm{a}$ and $8 \mathrm{~b}$ are taken, respectively, from a point just preceding the coda and from the very beginning of the coda. While literal superimposition is not present in Example 8b, nor in the last two measures of Example 8a, the effect of vertical combination of the $\mathrm{X}$ and $\mathrm{Y}$ triads ( $\mathrm{F}$ major and $\mathrm{A}$ minor) arises in performance because of the fast tempo and the pedalling. Example 8c shows a vertical association of $X$ and $Y$ from the climax of the coda. In all three passages, the subordinate role of $\mathrm{X}$ is made very obvious; the note $\mathrm{F}$, formerly the tonic, is now presented as a mere neighbour note embellishing the fifth of the new tonic triad of A minor.

\section{Foreshadowing and Recall in Mahler's Ninth Symphony}

Thus far, only early nineteenth-century deviating works have been investigated. In the latter half of the century, the practice of deviation remained prevalent; it was further explored by Wagner, Mahler, Wolf, Mussorgsky and others. Many of the acts of Wagner's music dramas are spanned by a systematically worked-out progression from one key to another (for example, the first act of Tristan und Isolde - A minor to $\mathrm{C}$ major - and the third act of Siegfried - G minor to $\mathrm{C}$ major). Mahler frequently employed deviation within individual movements of his symphonies, for example, in the last movement of his Second Symphony, in the first movement of his Third and in 
(156)

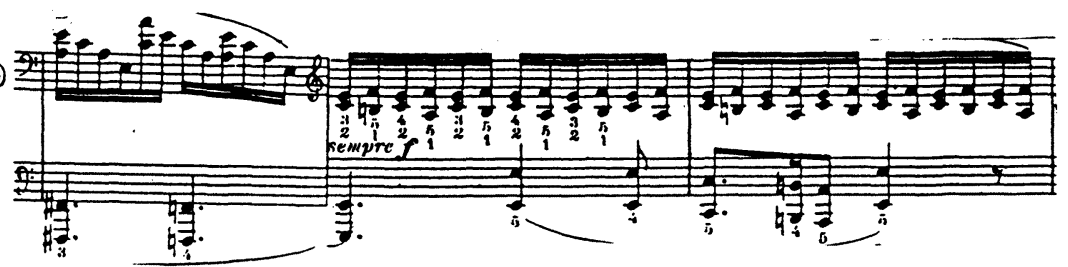

a

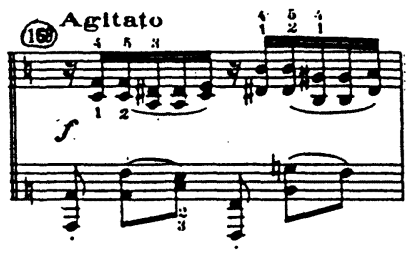

b

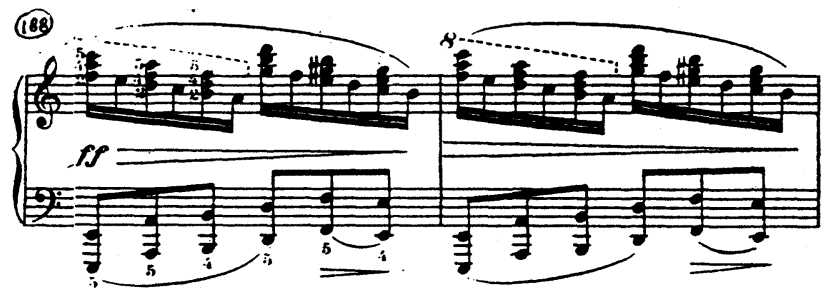

c

Example 8: Chopin, Ballade Op. 38. Recall by superimposition of $\mathrm{X}$ and $\mathrm{Y}$

the fourth movement of his Fourth. Mahler also applied deviation to entire symphonies; his Second, Fourth, Fifth, Seventh and Ninth Symphonies end in keys other than those with which they begin.

To be sure, various changes took place in the application of the practice of deviation in the late nineteenth century. First, the procedure was now more frequently employed over wide musical expanses - in large symphonic and dramatic structures, rather than only Lieder and piano pieces. Second, deviation was more often associated with tonal pairing, where $\mathrm{X}$ and $\mathrm{Y}$ are associated throughout a work in a double-tonic complex, and deviation results 
simply from a shift in emphasis from one component of the complex to the other. ${ }^{5}$ Little change, however, occurs in the application of techniques of foreshadowing and recall. Let us look at a late nineteenth-century deviating work which is particularly rich in such techniques, namely Mahler's Ninth Symphony.

Of all of Mahler's symphonies, the Ninth is indeed the least unified from the standpoint of tonality. In all of his other tonally deviating symphonies, the tonics of the opening or of the final movement fulfill a tonic function in at least one other movement. In the Ninth, on the other hand, each movement lies within a different key (D major, C major, A minor and D flat major, respectively). Techniques of unification, then, would seem to be particularly pertinent to this symphony. Mahler pulls the tonally diverse work together by various means, but prominent among them is the extensive use of foreshadowing and recall. ${ }^{6}$

Some of the applications of these techniques involve reference to the keys of the inner movements. For example, the last movement begins by recalling the keys of all three of the earlier movements. ${ }^{7}$ The opening violin line, while fitting into the key of D flat major $(\mathrm{Y})$, also sounds like a reference to the dominant of A minor, the key of the preceding movement. In measures 3, 7 and 9 there are statements of the dominant triad of D major, the key of the first movement $(\mathrm{X})$, while in measure 8 , the key of the second movement $(\mathrm{C}$ major) is recalled.

5 The terms "tonal pairing" and "double-tonic complex" are Robert Bailey's. See Wagner, Prelude and Transfiguration from "Tristan und Isolde", ed. Robert Bailey (New York and London: W. W. Norton and Co.), p. 121. The procedures associated with deviation in late nineteenth-century music have also been discussed by William Kinderman in "Dramatic Recapitulation in Wagner's Götterdämmerung," 19th Century Music IV/2 (Fall 1980), pp. 101-112; by Deborah Stein in Hugo Wolf's Lieder and Extensions of Tonality (Ann Arbor: UMI Research Press, 1985); and by Christopher Lewis in Tonal Coherence in Mahler's Ninth Symphony (Ann Arbor: UMI Research Press, 1984).

Christopher Lewis deals with other means of unification, particularly the thoroughgoing employment of a double-tonic complex, in his book Tonal Coherence in Mahler's Ninth Symphony (Ann Arbor: UMI Research Press, 1984).

Inclusion in this paper of all discussed excerpts of the Ninth Symphony would have been impracticable. The reader is asked to consult a score while reading the remainder of the paper. 
Mahler shows himself to be most concerned, however, with the tying together of the tonal endpoints of the symphony; most of the foreshadowing and recall involves preparation of the final key of $D$ flat major and reference back to the opening key of $D$ major. Foreshadowing of $Y$ is concentrated in the first movement. Exposed melodic $\mathrm{X}-\mathrm{Y}$ successions occur with considerable frequency. The first statement of the tonic note $\mathrm{D}$ is followed by a C sharp (m. 4). This melodic motion stands out because it lies higher than all earlier pitches and because it is approached and left by leap. Subsequent D-C sharp motions are even more conspicuous. In mm. 78-79, just prior to the beginning of a new section, the first horn announces this pitch succession; an accented D appears over a sustained chord in the low woodwinds and brasses. The following $\mathrm{C}$ sharp is accentuated not only by the elimination of the accompanying chord but also by "stopping." In mm. 130-132, the succession appears in the form of melancholy wails in the flutes over a low accompaniment. A similar $\mathrm{X} / \mathrm{Y}$ association is found in $\mathrm{mm} .416-417$, again in the flute part (with oboes).

Even more frequent in the first movement than melodic $\mathrm{X} / \mathrm{Y}$ association is the superimposition of $\mathrm{X}$ and $\mathrm{Y}$. The notes $\mathrm{D}$ and $\mathrm{C}$ sharp are conspicuously sounded together, for example, near the end of the movement. The resulting dyad, constituting the entire content of m. 426 and of half of m. 427, is emphasized by extended and isolated presentation. A more complex example of superimposition is found in $\mathrm{mm}$. 29-30; by the extensive use of chromatic embellishing tones ( $\mathrm{G}$ sharp and $\mathrm{C}$ sharp - appoggiaturas with delayed resolutions), a passage prolonging $\mathrm{X}$ is overlaid with hints at $\mathrm{Y}$. In addition, a chord combining elements of the $\mathrm{X}$ and $\mathrm{Y}$ triads, namely "D-F-A-C sharp", is consistently assigned great prominence in the first movement. It is associated with several of the impressive climaxes $(\mathrm{mm} .36-39, \mathrm{~m} .202$ and $\mathrm{mm}$. 374-375) and is also placed at significant points of the structure, specifically near section boundaries (see m. 29, mm. 261-263 and mm. 403-405).

The $\mathrm{X} / \mathrm{Y}$ conglomerate " $\mathrm{D}-\mathrm{F}-\mathrm{A}-\mathrm{C}$ sharp" is prominent in the horizontal as well as in the vertical dimension. One of the main themes of the first movement is an embellished arpeggiation of this chord. The note $\mathrm{G}$ sharp, introduced within this theme as a neighbour to $\mathrm{A}$, unites with $\mathrm{F}$ and $\mathrm{C}$ sharp to complete a $\mathrm{Y}$ triad. The theme thus consists of an interlocking of the $\mathrm{X}$ and $\mathrm{Y}$ triads (see mm. 29, 38-39, 81-82, 211-212, 239-247, 372-373, and the cello part in mm. 204-210). The latter statement clarifies the relation between the vertical and the horizontal $\mathrm{X} / \mathrm{Y}$ conglomerate; the melody is gradually carved out of the D-F-A-C sharp chord by the successive addition of embellishing tones.

Another melody that illustrates the simultaneous arpeggiation of $\mathrm{X}$ and $\mathrm{Y}$ is 

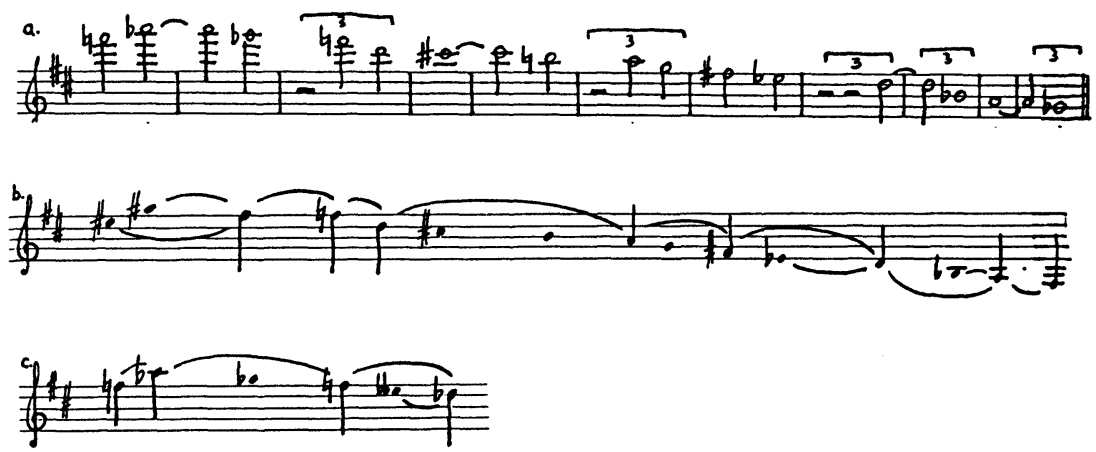

Example 9: Mahler, Ninth Symphony, first movement, mm. 423-433, flute part. Superimposed $\mathrm{X}$ and $\mathrm{Y}$ arpeggiations

found near the end of the first movement (mm. 423-433, see Example 9a). The melody as a whole can be heard as a highly ornamented arpeggiation of $\mathrm{X}$ (see Example 9b). The first portion, however, clearly outlines the Y triad as well, its root and fifth agogically accented (see Example 9c). Like all of the foreshadowing passages in the first movement, this one is rendered highly prominent, the melody played by the flute in a very high register over a rather static accompaniment.

Foreshadowing and recall are at a minimum in the second movement. The key of $\mathrm{D}$ is recalled in mm. 261-299; the section encompassed by those measures treats $\mathrm{D}$ as a tonic. There are, however, hints at the final key of $\mathrm{D}$ flat in the same passage. The cadence that ends the first phrase of the section $(\mathrm{mm}$. 261-264) consists of the progression $D$ flat to $D$. In a subsequent varied repetition of the phrase (mm. 291-294), the D flat triad becomes more prominent; the harmonic progression is altered in such a way that D flat replaces D as the endpoint of the phrase. The alteration of the phrase framework from "D-D" to "D-D flat" subtly anticipates the superseding of D by D flat at the end of the symphony.

Passages foreshadowing $\mathrm{Y}$ or recalling $\mathrm{X}$ are infrequent but prominent in the third movement. In much of this complex movement, so much happens so fast that the listener, at least on first contact with the work, can register little more than a blur of frantic activity. There are, however, a few areas that deeply invade even a first-time listener's consciousness; it is in these areas that Mahler applies foreshadowing and recall techniques. The first few measures, for example, make an impression not only because of their position at the 
opening of the movement but also because of their relatively long note values and because they are frequently reiterated (see mm. 64ff, 198ff, 615ff, 668ff). These measures spell out the progression I-V-I in Y (see mm. 1-2 - I of Y; m. $4-\mathrm{V}$ of $\mathrm{Y} ; \mathrm{m} .6-\mathrm{I}$ of $\mathrm{Y}$.

The area of the third movement that is most easily comprehended and that cannot fail to touch the listener deeply is the episode comprising mm. 347-443. This passage stands out with its departure from the demoniac atmosphere of the remainder of the movement, because of its long note values and somewhat slower tempo and, most important, because of its tonal stability; nowhere else in the movement do we so distinctly perceive a sense of tonality. Significantly, the key which Mahler lays out for us so clearly in this passage is D major (X). The central movements of the symphony, then, though they lie in keys other than $\mathrm{X}$ and $\mathrm{Y}$, do keep $\mathrm{X}$ alive while also hinting at $\mathrm{Y}$.

In the fourth movement, the foreshadowed key of D flat definitively comes into its own and the opening tonic is equally definitively dissolved. The main theme of the movement, frequently reiterated, contains several references to the dominant of $\mathrm{X}$ (see $\mathrm{mm}$. 3, 7, 9 and corresponding passages). In the second and in later statements of the theme, the X triad itself appears, often emphasized by a dynamic or agogic accent (see mm. 19, 51, 65, 127 and 139). All of these statements of the A major or D major triad are presented within passages prolonging $\mathrm{Y}$, so that the subordination of $\mathrm{X}$ to $\mathrm{Y}$ becomes evident.

Melodic successions in which the note $\mathrm{X}$ is subordinated to $\mathrm{Y}$ are abundant in the fourth movement. The first such succession appears in m. 24. At this important structural point - the end of the first maggiore section - the succession is presented in a high register by the second violins. The note $\mathrm{D}$ appears as a dissonant embellishment of a dominant chord, while $\mathrm{D}$ flat acts as the root of a tonic triad - a clear indication that $D$ is now to be understood as being of lesser significance than $\mathrm{D}$ flat. In the minore section, too, the melodic motion D-C sharp is presented in such a way that the secondary importance of $\mathrm{D}$ becomes apparent (see mm. 96, 97-98 and 108).

Chords built on the two tonic notes are prominently juxtaposed at two points. In mm. $23-24$, the progression " $N_{6}-V 6 / 4$ " is presented. The Neapolitan sixth chord within the prevailing $\mathrm{D}$ flat tonality is the $\mathrm{X}$ triad, while the succeeding cadential six-four chord consists of the notes of Y. In mm. 63-64, a climactic statement of the main theme in the key of $Y$ is approached by means of a major-minor seventh chord built on $X$, resulting in another dramatic association of the two tonics. In both progressions, $\mathrm{X}$ is clearly subordinate to $\mathrm{Y}$. 
The last example of subordination of $\mathrm{X}$ to $\mathrm{Y}$ is the most effective and the most beautiful. In mm. 146-152, the texture becomes progressively thinner and the dynamic level falls to a hush. In mm. 152 (last beat) to 154 (marked ersterbend - dying away), the violins and violas whisper a reference to the dominant of $\mathbf{X}$. The lower strings then join the violas in a more definite statement of that dominant. The subsequent reference by the cellos to the introductory melody of the movement (mm. 157-158) is still heard as belonging to the dominant of $\mathrm{X}$; given the preceding emphasis on A major harmony, the Eb of mm. 157-158 sounds like an appoggiatura to the third of that harmony, and the notes $\mathrm{Db}, \mathrm{Cb}$ and $\mathrm{Bbb}$ in $\mathrm{m}$. 158 are heard as $\mathrm{C}-\mathrm{B}-\mathrm{A}$. During a pause, the A major harmony hangs in the air. Then, very slowly, haltingly, the dominant of $\mathrm{Y}$ is introduced (mm. 159-160), clearly reestablishing the final key on the surface level. That key reigns undisturbed to the end of the symphony.

Thus, a chord which originally belonged to the domain of $\mathrm{X}$ has been given a new function within the domain of Y, namely the function of an augmented sixth chord, and has participated in the final establishment of that final tonic. We have witnessed the Ersterben - the ultimate dissolution - of X and its absorption by Y.

Mahler's Ninth Symphony, then, is not a haphazard juxtaposition of movements in different keys. The final key is assiduously prepared from the outset. Small-scale D-C sharp successions foreshadow the overall tonal progression of the symphony. Superimposition of elements of the D and D flat triads set up an ongoing conflict between those triads which is in the end resolved in favour of D flat. Frequent recall of the opening tonic after the first movement keeps that triad alive and prevents it from remaining a loose end. Finally, in a moment of supreme beauty, this potential loose end is definitively tied into the final tonic of D flat major. The fact that a great deal of the foreshadowing and recall is presented in a very prominent manner suggests that Mahler was concerned that it should penetrate the listener's consciousness and help him or her to perceive the inner unity of the symphony.

The non-existence in a given work of a single, all-connecting tonal thread, then, need not result in a chaotic harmonic tangle. The discovery that coherent tonal tapestries can be created by the artful intertwining of two tonal threads as well as by the spinning out of a single one is among the most important outcomes of the harmonic explorations of nineteenth-century composers. 